The 24th Lung Cancer Workshop

当院における外来化学療法の現況

一悪性胸膜中皮腫に対するペメトレキセド+シスプラチン併用療法の

外来化学療法における安全性の検討一

\author{
福岡和也 1,2 ・栗林康造 1 ・藤盛好啓 2 ・中野孝司 1,2
}

\title{
Evaluation of the Safety Profiles of Pemetrexed in Combination with Cisplatin for Malignant Pleural Mesothelioma in an Outpatient Clinic
}

Kazuya Fukuoka1,2; Kozo Kuribayashi1; Yoshihiro Fujimori2; Takashi Nakano1,2
${ }^{1}$ Division of Respiratory Medicine, Department of Internal Medicine, ${ }^{2}$ Cancer Center, Hyogo College of Medicine, Japan.

ABSTRACT - Objective. To evaluate the safety profile of combination therapy of pemetrexed plus cisplatin for malignant pleural mesothelioma (MPM) in an outpatient clinic. Methods. Patients received an intravenous infusion of $500 \mathrm{mg} / \mathrm{m}^{2}$ pemetrexed followed by an intravenous infusion of $60-75 \mathrm{mg} / \mathrm{m}^{2}$ cisplatin, on day 1 of every 21 days, concomitantly with vitamins. Results. We analyzed total of 105 patients who received combination therapy of pemetrexed plus cisplatin, after a histological diagnosis of MPM, but who had received no prior systemic chemotherapy, 77 (64 men, 13 women) of whom continued to receive this combination therapy as outpatients. The median age was 62.2 (range, 44 to 77). Epithelioid histology was present in 65 patients and 12 patients had non-epithelioid histology. There were 285 cycles administered in the outpatient setting, with a median cycle of 3 (range, 1 to 11). Hematological toxicities of grade $\geq 3$ included leukopenia in 10 patients $(13.0 \%)$, neutropenia in 15 patients (19.5\%), and anemia in 8 patients (10.4\%). Neither febrile neutropenia nor neutropenic infection was observed. Common non-hematological toxicities were gastrointestinal toxicities, such as nausea, constipation, anorexia, and vomiting, although toxicities of grade $\geq 3$ were not observed. Other grade 3 adverse events were neurotoxicity and allergic reaction in 1 and 2 patients, respectively. The most common abnormal laboratory findings were increased creatinine levels in 21 patients $(27.3 \%)$, followed by increased aminotransferase levels in 12 patients (15.6\%). There were no treatment-related deaths. Conclusion. The safety of this combination therapy was confirmed in outpatients with MPM.

(JJLC. 2011;51:109-112)

KEY WORDS — Malignant pleural mesothelioma, Pemetrexed, Cisplatin, Chemotherapy, Outpatient

Reprints: Kazuya Fukuoka, Division of Respiratory Medicine, Department of Internal Medicine, Hyogo College of Medicine, 1-1 Mukogawa-cho, Nishinomiya, Hyogo 663-8501, Japan (e-mail: kfukuoka@hyo-med.ac.jp).

要旨一一目的. 悪性胸膜中皮腫 (MPM) に対するペメ トレキセド+シスプラチン併用療法の外来化学療法にお ける安全性を検討する. 方法. 対象は病理組織学的に MPM と診断された前化学療法歴のない症例. 方法は, ビ タミン併用下, 3 週間隔で day 1 にペメトレキセド $(500$ $\left.\mathrm{mg} / \mathrm{m}^{2}\right)$ およびシスプラチン $\left(60 \sim 75 \mathrm{mg} / \mathrm{m}^{2}\right)$ を静脈内 投与した. 結果. 本併用療法を受けた 105 例のうち, 77 例が外来化学療法にて治療を継続した。性別は，男性 64
例, 女性 13 例. 平均年齢は 62.2 歳 (44 77 歳). 組織型 は上皮型 65 例, 非上皮型 12 例. 総投与サイクル数は 285 で, 中央值は $3(1 \sim 11)$. グレード 3 以上の血液毒性は白 血球数減少 10 例 $(13.0 \%)$, 好中球数減少 15 例 $(19.5 \%)$, 貧血 8 例 $(10.4 \%)$ であった. 発熱性好中球減少および好 中球減少時の感染はなかった. 主な非血液毒性は, 悪心, 便秘, 食欲不振, 嘔吐などの消化器毒性であったが, グ レード 3 以上は認められなかった。 その他のグレード 3 
の有害事象は, 神経障害 1 例とアレルギー反応 2 例で あった. 最も一般的な臨床検査項目異常は, 血中クレア チニン上昇 21 例 $(27.3 \%)$, 血中アミノトランスフェラー ゼ上昇 12 例 $(15.6 \%)$ であった. 治療関連死を認めなかっ
た. 結論. MPM に対する本併用療法の外来化学療法に おける安全性が確認された.

索引用語——悪性胸膜中皮腫, ペメトレキセド, シスプ ラチン, 化学療法, 外来患者

\section{はじめに}

癌化学療法の主な目的は, 患者の生存期間延長と quality of life（以下，QOL と略す）向上にある．新しい抗癌 剤の開発や支持療法の進歩に伴い, 患者の QOL は向上 し, 癌化学療法を外来で施行することができるように なった。また, 2002 年の診療報酬改定以後, 要件を満た す施設では外来化学療法加算の算定が可能となり，外来 化学療法は経済的効果を生み出すことからも, 現在, 多 くの施設で積極的に実施されている. 本ワークショップ では当院における外来化学療法の現況を中心に発表す る.

\section{がんセンター外来化学療法室の概要}

兵庫医科大学病院 (病床数 1006 床) は, 1972 年に開設 され, 1994 年に特定機能病院の認可を, 2008 年からは地 域がん診療連携拠点病院の指定を受けて今日に至る. 2005 年 7 月から, 既存の時間外外来診療室を利用して 10 床の外来化学療法室が開設された. 当初は, 呼吸器内科, 消化器内科, 婦人科の 3 科が参画し, 専任薬剤師および 看護師が各 2 名ずつの人員配置で運用が開始された. 2007 年 11 月, 当院がんセンター開設に伴い, 20 床に増 床した外来化学療法室が新設された.これを契機に, ど の診療科でも利用可能なオープンシステムが採用され，

人員配置も, 専任医師 1 名, 専任薬剤師および看護師各 3 名, 兼任ソーシャルワーカー 1 名, 各診療科担当医師に 拡充された. 開設当初の化学療法件数は，月間 150～200 件であったが, がんセンター外来化学療法室として拡充 以後, 件数は徐々に増加し, 現在では月間 450 件を超え ている. 診療科別では, 呼吸器内科および肝胆膵外科が 多く, 2007 年 11 月から 2008 年 10 月までの 1 年間にお ける外来化学療法室の利用者延べ人数は 2590 名 (呼吸器 内科 $60.0 \%$, 消化器内科 $16.9 \%$, 外科 $14.2 \%$, 婦人科 $7.4 \%$, 血液内科 $1.5 \%$ ) であった. 癌腫別の化学療法件数 では, 肺癌が最も多く, 肝・胆・膵癌, 大腸癌, 乳癌, 中皮腫と続く. 当院の特徵としては, 中皮腫に対する化 学療法件数が他施設に比較して多いことが挙げられる.

\section{化学療法レジメン・プロトコール管理}

癌化学療法を安全に実施するには, レジメンの収集と
処方鑑査が必要となる. 当院では抗癌剤および前投与薬 の投与方法や溶解液などを統一することで, 調剤ミスや ミキシングミスの防止に努め, 投薬ミスの軽減や治療時 間の短縮を図っている。プロトコールは登録制で, 各癌 腫のガイドラインや文献などからエビデンスとなる原典 を参照して作成される。実際に外来化学療法を実施する にあたっては，化学療法プロトコール票および各症例の 化学療法通知票を予め外来化学療法室へ提出しなければ ならない. 各診療科別の登録プロトコール数では呼吸器 内科が最多で, 合計約 150 のプロトコールが登録されて いる. 当科の特徵としては, シスプラチンを含む併用療 法のプロトコールも数多く含まれることが挙げられる.

\section{悪性胸膜中皮腫に対するペメトレキセド+シスプラ チン併用療法の外来化学療法における安全性の検討}

現在, ペメトレキセド+シスプラチン併用療法は, 悪 性胸膜中皮腫のみならず非小細胞肺癌, 特に非扁平上皮 癌に対するファーストラインの化学療法として認識され ている.1-3 今回, 悪性胸膜中皮腫を対象としてペメトレ キセド+シスプラチン併用療法の外来化学療法における 安全性をレトロスペクティブに検討した.

対象は, 2007 年 1 月から 2009 年 10 月までの間, ペメ トレキセド+シスプラチン併用療法を施行した前化学療 法歴のない悪性胸膜中皮腫 105 例中, 入院から外来化学 療法への移行が可能であった 77 例である.

治療方法は, 1 サイクル目を入院にて施行し有害事象 が耐容可能であれば，原則として 2 サイクル目以降を外 来化学療法で施行した. 独自に作成したクリニカルパス に従って, ペメトレキセドは 21 日を 1 サイクルとして, 各サイクルの 1 日目に $500 \mathrm{mg} / \mathrm{m}^{2}$ を 10 分間かけて点滴 静脈内投与した. シスプラチンは 21 日を 1 サイクルとし て，各サイクルの 1 日目にペメトレキセドを投与した 30 分後に引き続き, $60 〜 75 \mathrm{mg} / \mathrm{m}^{2}$ を 2 時間かけて点滴静 脈内投与した．点滴所要時間は，約 7 時間であった。必 須併用薬として, ペメトレキセド初回投与の 7 日以上前 から, 総合ビタミン剤およびビタミン $\mathrm{B}_{12}$ 製剤の投与を 開始した。総合ビタミン剤は $1 \mathrm{~g}$ （葉酸 $500 \mu \mathrm{g}$ 含有）を 1 日 1 回, 連日経口投与し, ビタミン $\mathrm{B}_{12}$ 製剤は 1 回 $1 \mathrm{mg}$ を 9 週ごとに筋肉内投与した.

外来化学療法の安全性は有害事象の種類, 発現頻度お 
Table 1. Patient Characteristics

\begin{tabular}{lc}
\hline Treated patients & 77 \\
\hline Mean age & 62.2 years \\
[range] & {$[44-77]$} \\
Gender: men/women & $64 / 13$ \\
Histologic type: ep/non-ep & $65 / 12$ \\
Primary site: right/left & $50 / 27$ \\
Stage: I/II/III/IV & $19 / 13 / 16 / 29$ \\
PS: $0-1 / 2$ & $74 / 3$ \\
\hline
\end{tabular}

ep, epithelioid; PS, performance status.

Table 2. Treatment Exposure

\begin{tabular}{lc}
\hline Total number of cycles administered: & 285 \\
Median number of cycles: & 3 \\
[range] & $1-11$ \\
\hline Average dosage $\left(\mathrm{mg} / \mathrm{m}^{2}\right)$ & \\
$\quad$ [range] & \\
Pemetrexed: & 492.5 \\
& {$[375-500]$} \\
Cisplatin: & 67.2 \\
& {$[45-75]$} \\
\hline
\end{tabular}

Table 3. Hematological Toxicities

\begin{tabular}{lccc}
\hline Adverse events & $\begin{array}{c}\text { All grades } \\
(\%)\end{array}$ & $\begin{array}{c}\text { Grade } 3 \\
(\%)\end{array}$ & $\begin{array}{c}\text { Grade 4 } \\
(\%)\end{array}$ \\
\hline Anemia & $68(88.3)$ & $6(7.8)$ & $2(2.6)$ \\
Leukopenia & $51(66.2)$ & $9(11.7)$ & $1(1.3)$ \\
Neutropenia & $47(61.0)$ & $9(11.7)$ & $6(7.8)$ \\
Thrombocytopenia & $18(23.4)$ & 0 & 0 \\
Febrile neutropenia & 0 & 0 & 0 \\
Neutropenic infection & 0 & 0 & 0 \\
\hline
\end{tabular}

よび重症度にて評価した. 重症度は, National Cancer Institute Common Terminology Criteria for Adverse Events (NCI-CTCAE) version 3.0 に準拠して判定した.

症例背景因子をTable 1 に示す. 平均年齢は 62.2 歳 （44～77 歳), 性別は男性 64 例, 女性 13 例, performance status (PS) は 0〜1 が 74 例， 2 が 3 例であった。組織型 は, 上皮型 65 例，非上皮型が 12 例であった。臨床病期 は IV 期が 29 例と最も多く，III 期が 16 例，II 期が 13 例, I 期が 19 例であった.

治療内容を Table 2 に示す．外来化学療法に扮ける総 投与サイクル数は 285 であった．症例ごとの投与サイク ル数は最長で 11 サイクル, 最短が 1 サイクルで, 中央值 は 3 サイクルであった (Table 2). 各薬剤の平均投与量 は, ペメトレキセド $492.5 \mathrm{mg} / \mathrm{m}^{2}\left(375 \sim 500 \mathrm{mg} / \mathrm{m}^{2}\right)$, シ スプラチン $67.2 \mathrm{mg} / \mathrm{m}^{2} \quad\left(45 \sim 75 \mathrm{mg} / \mathrm{m}^{2}\right)$ であった.
Table 4. Non-hematological Toxicities-I

\begin{tabular}{lccc}
\hline Adverse events & $\begin{array}{c}\text { All grades } \\
(\%)\end{array}$ & $\begin{array}{c}\text { Grade } 2 \\
(\%)\end{array}$ & $\begin{array}{c}\text { Grade 3 } \\
(\%)\end{array}$ \\
\hline Nausea & $31(40.3)$ & $14(18.2)$ & 0 \\
Vomiting & $5(6.5)$ & $2(2.6)$ & 0 \\
Constipation & $15(19.5)$ & $2(2.6)$ & 0 \\
Diarrhea & $2(2.6)$ & 0 & 0 \\
Anorexia & $6(7.8)$ & $4(5.2)$ & 0 \\
Dysgeusia & $3(3.9)$ & 0 & 0 \\
Hiccoughs & $4(5.2)$ & $2(2.6)$ & 0 \\
Stomatitis & $2(2.6)$ & 0 & 0 \\
\hline
\end{tabular}

Table 5. Non-hematological Toxicities-II

\begin{tabular}{lccc}
\hline Adverse events & $\begin{array}{c}\text { All grades } \\
(\%)\end{array}$ & $\begin{array}{c}\text { Grade } 2 \\
(\%)\end{array}$ & $\begin{array}{c}\text { Grade 3 } \\
(\%)\end{array}$ \\
\hline Hepatic toxicity & $12(15.6)$ & $2(2.6)$ & 0 \\
Renal toxicity & $21(27.3)$ & $1(1.3)$ & 0 \\
Hyponatremia & $3(3.9)$ & - & $3(3.9)$ \\
Fatigue & $6(7.8)$ & $1(1.3)$ & 0 \\
Neurotoxicity & $4(5.2)$ & 0 & $1(1.3)$ \\
Tinnitus & $1(1.3)$ & $1(1.3)$ & 0 \\
Allergic reaction & $2(2.6)$ & 0 & $2(2.6)$ \\
Pulmonary toxicity & 0 & 0 & 0 \\
\hline
\end{tabular}

安全性の評価に関して, 血液毒性の結果を Table 3 に 示す. 白血球数減少, 好中球数減少がそれぞれ, 51 例 (66.2\%), 47 例 (61.0\%) に認められた。このうち, グレー ド 3 以上は, 白血球数減少が 10 例 $(13.0 \%)$, 好中球数減 少が 15 例 $(19.5 \%)$ であった。発熱性好中球減少および 好中球減少時の感染は認められなかった. 貧血は 68 例 (88.3\%)に認められたが, グレード 3 以上は 8 例 (10.4\%) であった．血小板数減少は 18 例 $(23.4 \%)$ に認められた が, グレード 3 以上は認められなかった.

非血液毒性のうち, 主な消化器毒性は悪心が 31 例 (40.3\%), 便秘が 15 例 (19.5\%), 食欲不振が 6 例 (7.8\%), 嘔吐が 5 例 $(6.5 \%)$ に認められたが，すべてグレード 1 2 であった（Table 4$)$.

臨床検査項目異常を含むその他の非血液毒性では, 血 中クレアチニン上昇による腎機能障害が 21 例 (27.3\%), 血中アミノトランスフェラーゼ上昇による肝機能障害が 12 例 $(15.6 \%)$, 倦总感が 6 例 $(7.8 \%)$, 神経障害が 4 例 $(5.2 \%)$, 低ナトリウム血症が 3 例 (3.9\%), アレルギー 反応が 2 例 $(2.6 \%)$ に認められた。この中で，低ナトリ ウム血症を除くグレード 3 の有害事象は, 神経障害の 1 例とアレルギー反応の 2 例のみであった (Table 5).これ らの 3 例は, 有害事象発生後, 本併用化学療法を終了し た. なお, 肺毒性および治療関連死は認められなかった. 
以上より，悪性胸膜中皮腫を対象としてペメトレキセ ド+シスプラチン併用療法の外来化学療法における安全 性が確認された。主な有害事象は, 白血球数減少, 好中 球数減少および貧血であった，悪心，嘔吐などの消化器 毒性の頻度はこれまでの報告と比較して少ない傾向に

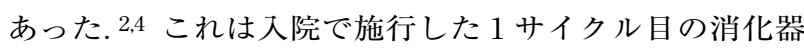
毒性の程度によっては, 外来化学療法において制吐療法 を強化した症例があったことが一因と考えられた.

\section{おわりに}

癌化学療法を実施していくには, 患者と各医療従事者 がお互いに連携して協力していくことが必要不可欠であ る.また, 癌患者の心のケアにも細心の配慮を払わなけ ればならない. 当院においては, 薬侴師は処方チェック や疑義照会, 薬歴管理, 無菌的調剤, 薬剤説明などを, 看護師は有害事象のグレード評価, 日常生活支援, 予約 枠管理，点滴管理パンフレットを用いたオリエンテー ションを担当している. チーム医療・連携を効果的に実 践し, 支持療法などに反映していくことが, 外来化学療 法を受ける癌患者の QOL 向上に寄与するものと考え
る。

\section{REFERENCES}

1. Vogelzang NJ, Rusthoven JJ, Symanowski J, Denham C, Kaukel E, Ruffie P, et al. Phase III study of pemetrexed in combination with cisplatin versus cisplatin alone in patients with malignant pleural mesothelioma. J Clin Oncol. 2003;21:2636-2644.

2. Nakagawa K, Yamazaki K, Kunitoh H, Hida T, Gemba K, Shinkai $\mathrm{T}$, et al. Efficacy and safety of pemetrexed in combination with cisplatin for malignant pleural mesothelioma: a phase I/II study in Japanese patients. Jpn J Clin Oncol. 2008;38:339-346.

3. Scagliotti GV, Parikh P, von Pawel J, Biesma B, Vansteenkiste J, Manegold C, et al. Phase III study comparing cisplatin plus gemcitabine with cisplatin plus pemetrexed in chemotherapy-naive patients with advanced-stage non-small-cell lung cancer. J Clin Oncol. 2008;26:3543-3551.

4. 福岡和也, 本村文宏, 國頭英夫, 樋田豊明, 中川和彦, 玄 馬顕一，他. 悪性胸膜中皮腫を対象としたLY231514(ぺ メトレキセド）とシスプラチン併用療法の安全性情報収 集のための臨床試験. 肺癌. 2009;49:988-993. 